\title{
Improving thermal performance of an existing UK district heat network: a case fortemperature
} optimization

\section{Authors}

Michele Tunzi ${ }^{a}$, Rabah Boukhanouf ${ }^{\mathrm{b}}$, Hongwei $\mathrm{Li}^{\mathrm{c}}$, Svend Svendsen ${ }^{\mathrm{c}}$, Anton Ianakiev ${ }^{\mathrm{d}}$

*Corresponding author. Tel: +44 75447012 47, E-mail address: M.Tunzi@lboro.ac.uk

a School of Civil \& Building Engineering, Loughborough University, LE11 3TU, Loughborough, UK

b Department of Architecture and Built Environment, University of Nottingham, NG7 2RD, Nottingham, UK

c Department of Civil Engineering, Technical University of Denmark, Brovej, Building 118, DK-2800 Kgs. Lyngby, Denmark

${ }^{\mathrm{d}}$ Department of Civil Engineering, Nottingham Trent University, NG1 4BU, Nottingham, UK

Keywords: Plate radiators, temperature optimization, low temperature district heating, heat network modelling

\section{Highlights}

- Optimization of plate radiators operating temperature

- Modelling and optimization of low temperature district heat network thermal performance

- Method of investigating and improving performance of existing heating systems connected to district heat network

\begin{abstract}
This paper presents results of a research study into improving energy performance of small-scale district heat network through water supply and return temperature optimization technique. The case study involves establishing the baseline heat demand of the estate's buildings, benchmarking the existing heat network operating parameters, and defining the optimum supply and return temperature. A stepwise temperature optimization technique of plate radiators heat emitters was applied to control the buildings indoor thermal comfort using night set back temperature strategy of $21 / 18{ }^{\circ} \mathrm{C}$. It was established that the heat network return temperature could be lowered from the current measured average of $55{ }^{\circ} \mathrm{C}$ to $35.6{ }^{\circ} \mathrm{C}$, resulting in overall reduction of heat distribution losses and fuel consumption of $10 \%$ and $9 \%$ respectively. Hence, the study demonstrates the potential of operating existing heat networks at optimum performance and achieving lower return temperature. It was also
\end{abstract}


pointed out that optimal operation of future low temperature district heat networks will require close engagement between the operator and the end user through incentives of mutual benefit.

\section{Introduction}

The decarbonization of the UK heat market is becoming central to achieve the country's emission targets as it accounts for nearly half of total primary energy consumption [1], [2]. In line with the EU energy policy, UK has outlined its own domestic targets where a reduction of $50 \%$ and $80 \%$ compared to 1990 carbon emissions level were set respectively for 2027 and 2050 [3]. Among the many solutions envisaged for the heat market, district heat networks (DH) offer the flexibility and capacity for faster integration of low emission heat-generating sources for a smooth transition towards a low carbon society [4]. It is projected that DH technology could supply cost effectively $14 \%$ and $43 \%$ of the total UK heat demand in buildings by 2030 and 2050 respectively [1] [5]. Moreover, to keep pace with the current development on reducing energy consumption in buildings through improving thermal insulation involving construction materials, which affect heat demand in buildings, the DH technology is undergoing significant improvement to reduce heat distribution losses, increase heat generation efficiency and lower carbon emission [5].

The renewed focus of DH is to develop new technologies, methods and intelligent controls where the current practice of constant operating supply/return temperatures of typically $80 / 40{ }^{\circ} \mathrm{C}$ is replaced by load-dependent temperatures where supply and return temperatures are as low as 50/20 ${ }^{\circ} \mathrm{C}$, a system referred to in literature as $4^{\text {th }}$ generation DH (4GDH) [6]. The new concept of low temperature district heating (LTDH) for low energy buildings and for buildings at different level of refurbishment has been reported in several studies [7]-[12]. Other investigations shown that hot water supply temperatures even lower than $50{ }^{\circ} \mathrm{C}$ are technically adequate to guarantee the same indoor comfort standards [13]-[15]. For instance, Østengaard and Svendsen [16] studied the operation of plate radiators in old Danish single-family house built in 1900s and found that depending on the level of renovation, these properties can be heated with district heating supply temperatures below $50{ }^{\circ} \mathrm{C}$ for the majority of the heating season. Furthermore, the lower boundary for hot water supply temperature is only limited if domestic hot water is also required. In compliance with current regulation on 
legionella bacterium in the UK, domestic hot water storage tanks must kept at a temperature of about $60{ }^{\circ} \mathrm{C}$, whereas $50{ }^{\circ} \mathrm{C}$ has to be guaranteed in one minute in the secondary circuit for the case of instantaneous DHW preparation [6], [17]-[19]. In countries with large DH market, as for Denmark, the comfort temperature instead has to reach $45^{\circ} \mathrm{C}$ in 10 seconds according to national policy DS 439 [20]. Therefore, in low and ultra-low DH networks, with supply temperatures equal or below $50{ }^{\circ} \mathrm{C}$, DHW temperature would need to be increased to deliver sanitary water safely through, for example, a separate heating device such as electric heaters or micro heat pumps, as presented by Yang et al. [21][23].

Implementing LTDH requires, however, that the design and operation of heat emitting appliances in buildings be correctly performed to achieve the desired thermal comfort. In existing buildings with traditional high temperature radiators installation, it is crucial to carry out a correct diagnosis for supply and return temperature based on prevailing ambient conditions. It is common practice in the industry that hydronic radiators are oversized to afford indoor comfort in extreme short cold periods; while for the majority of the heating season the installation will operate at part load and lower operating temperatures will be adequate to satisfy heat loads [24]. For example, in well-developed DH markets as in Denmark radiators are designed for typical heat supply at $70 / 40{ }^{\circ} \mathrm{C}$; whereas in Finland $80 / 60{ }^{\circ} \mathrm{C}$ was the common practice for high temperature radiators. This was reduced to 55/45 ${ }^{\circ} \mathrm{C}$ and $40 / 30{ }^{\circ} \mathrm{C}$ for medium and low temperatures radiators respectively [25]. In Sweden instead, radiators with design temperatures higher than $60^{\circ} \mathrm{C}$ were phased out since 1980 s and current design standards are $55 / 45^{\circ} \mathrm{C}$ [26], [27].

In comparison, the UK heating market is still lagging behind most of the EU countries as it is still normal practice to install radiators of high design temperature $\left(82 / 71{ }^{\circ} \mathrm{C}\right)$ and small temperature difference $(\Delta \mathrm{T})$ [28]. With the proliferation of low energy homes and the expansion of the refurbishment program of the housing stock, the heat market will inevitably shift towards low temperature heat systems. This is attested by the recent Chartered Institution of Building services Engineers (CIBSE) and Association for Decentralised Energy (ADE) publication on DH networks design and specification [29], which highlights among other design recommendations the shift to embrace lower temperature of $70 / 40{ }^{\circ} \mathrm{C}$ radiator designs. 
This work addresses the specific need for considering lower heat supply temperature in UK heat market as a prelude for lower energy consumption and carbon emission. In this context, the paper presents a design strategy for effective optimisation of return water temperature in existing and future heat networks installations. The proposed temperature optimization methodology, developed by the authors in a previous study [30], was tested on an existing UK small-scale heat network case study. Currently, there are not many meaningful studies investigating the transition of existing heat network towards LTDH in the UK and this paper contributes directly to advancing the discussion on implementing DH at national level and provides a tool to support the decision of designers and DH operators

$2 \quad$ Small scale DH case study

The case study represents an isolated small-scale DH network supplying space heating only to different types of buildings located on a farmland north of Nottingham city, UK. Figure 1 shows the aerial view of the estates and layout of the $\mathrm{DH}$.

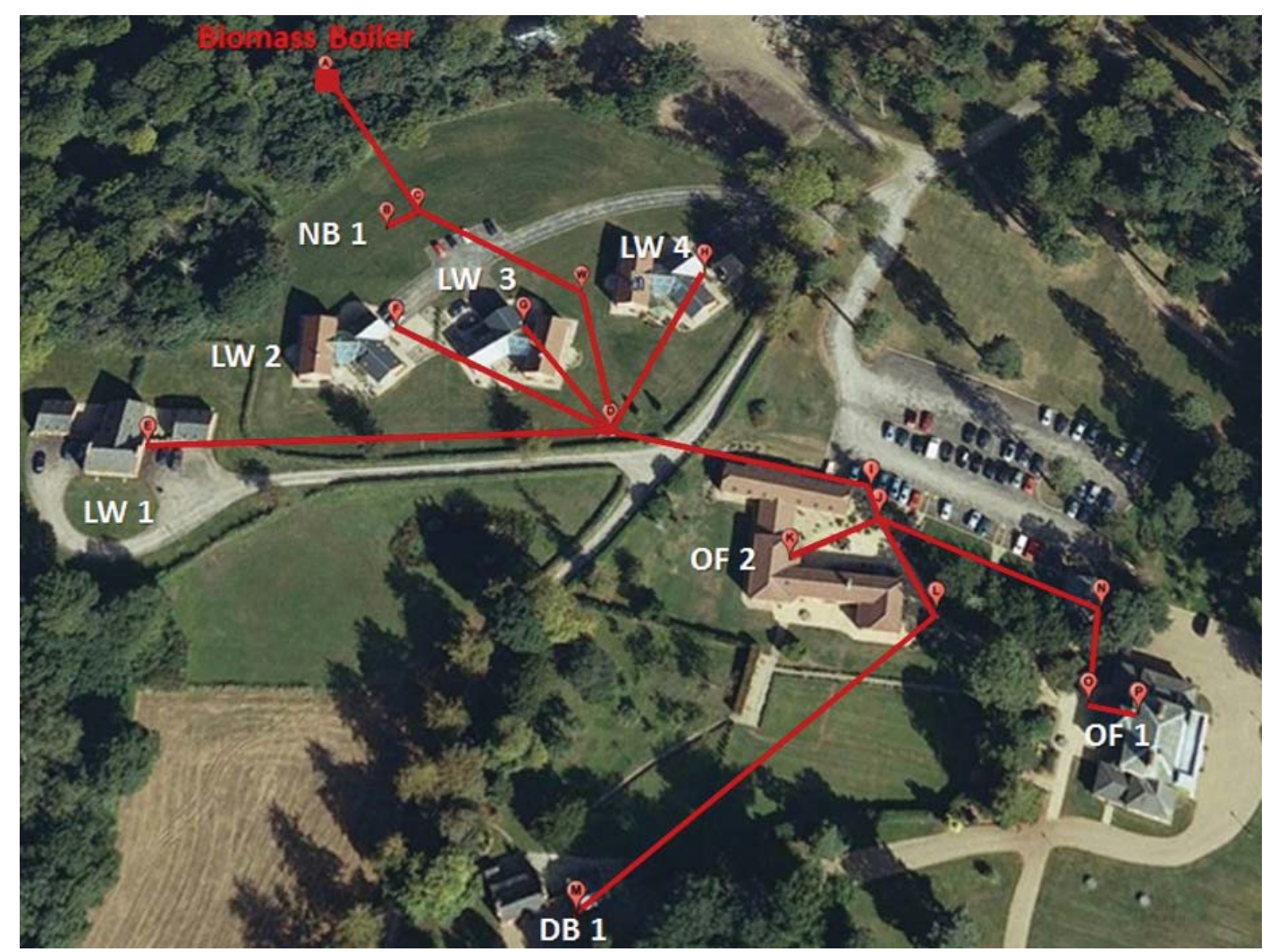

Figure 1: Building estate aerial view and heat network layout 
The heat network is about 10 years old and serves eight buildings including two office buildings (OF 1 and OF 2), one domestic building (DB 1), four Live/Work buildings (LW 1 - LW4) and one newly built Live/Work building (NB 1). Building NB 1 was connected to the DH network after the completion of this study and was disregarded in this paper. The building LW 1 to LW4 combine the activity of office work and living space environment. Table 1 shows occupancy type and floor area of each building.

Table 1: Buildings' highlights

\begin{tabular}{cccc}
\hline Building & Office occupants & Domestic occupants & Total floor area $\left(\mathbf{m}^{2}\right)$ \\
\hline LW 1 & 4 & 2 & 256 \\
LW 2 & 3 & 2 & 535 \\
LW 3 & 4 & 2 & 535 \\
LW 4 & 3 & 2 & 535 \\
DB 1 & - & 2 & 209 \\
OF 1 & 33 & - & 760 \\
OF 2 & 35 & - & 561 \\
\hline
\end{tabular}

\subsection{Buildings construction properties and performance}

The Estate combines a mix of different buildings characterized by different energy consumption, activities and heating systems. Building OF 2, DB 1 and LW 1 are existing buildings which were renovated before 2006 whereas building LW 2, 3 and 4 are identical new buildings constructed according to UK Building Regulations 2006 Part L1A (Conservation of fuel and power in new dwellings ) [31], [32]. The largest building of the estate OF 1, is used as office space and is also a listed "Grade II" building according to the UK building regulations of historic and traditionally constructed buildings [33]. To preserve the architecture heritage, this type of buildings cannot be renovated and only the roof was replaced after being damaged. The construction data of the elements of the buildings is summarized in Table 2 . 
Table 2: Buildings construction properties

\begin{tabular}{|c|c|c|c|c|c|}
\hline Building & Element & Type & $\begin{array}{c}\text { U-value } \\
\left(\mathbf{W} / \mathbf{m}^{2} \mathbf{K}\right)\end{array}$ & $\begin{array}{c}\text { Thickness } \\
\text { (m) }\end{array}$ & $\begin{array}{c}\text { Air permeability } \\
\left(\mathrm{m}^{3} / \mathbf{h} \mathbf{~ m}^{2}\right) \text { at } 50 \mathrm{~Pa}\end{array}$ \\
\hline & Wall & Solid brick & 2.09 & 0.60 & \\
\hline \multirow{3}{*}{ OF 1} & Roof & Tiles & 0.35 & 0.25 & \multirow{3}{*}{$<\mathrm{v}$} \\
\hline & Floor & Suspended timber & 0.7 & 0.3 & \\
\hline & Windows & Single glazing & 4.9 & & \\
\hline \multirow{4}{*}{$\begin{array}{c}\text { OF 2, DB 1, } \\
\text { LW } 1\end{array}$} & Wall & Brick-cavity & 0.7 & 0.4 & \multirow{4}{*}{ ' } \\
\hline & Roof & Tiles & 0.7 & 0.25 & \\
\hline & Floor & Suspended timber & 0.7 & 0.3 & \\
\hline & Windows & Double glazing & 2.9 & & \\
\hline \multirow{4}{*}{$\begin{array}{l}\text { LW 2, LW 3, } \\
\text { LW } 4\end{array}$} & Wall & Brick-cavity & 0.35 & 0.4 & \multirow{4}{*}{ ' } \\
\hline & Roof & Tiles & 0.35 & 0.25 & \\
\hline & Floor & Suspended timber & 0.35 & 0.3 & \\
\hline & Windows & Double glazing & 2.9 & & \\
\hline
\end{tabular}

Using CIBSE standards for office areas, typical heat gains values of 12 and $15 \mathrm{~W} / \mathrm{m}^{2}$ were assumed respectively for lighting and equipment - including computers and office equipment; and $5 \mathrm{~W} / \mathrm{m}^{2}$ was considered for internal heat gains in the case of domestic spaces [34]. It was assumed that the Work space was occupied from 9:00 to 18:00 while Live space occupancy follows that of typical UK domestic dwelling except during "office time”, when there is dual use of kitchen space in the LiveWork buildings (LW 1, 2, 3 and 4). The indoor comfort for all buildings is controlled by night setback strategy with target temperatures of $21 / 18{ }^{\circ} \mathrm{C}$. An example of recorded indoor temperatures for two rooms of OF 1 and DB 1 is presented in Figure 2.
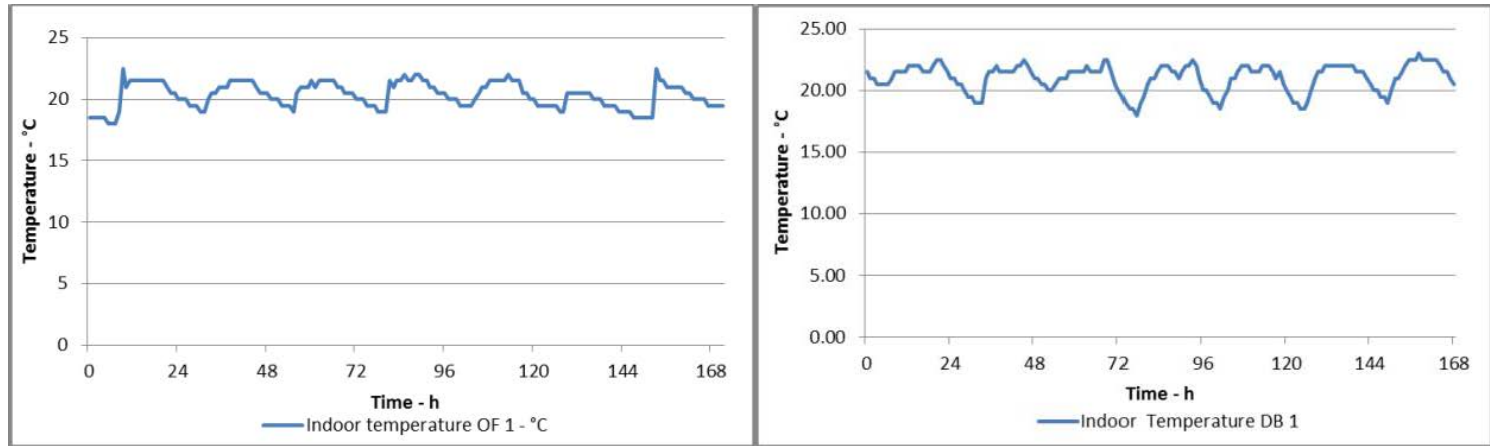

Figure 2: Indoor temperature recording for two rooms of building OF 1 and DB 1

The night setback strategy is normally used to reduce the indoor temperature during night and use the building's thermal mass to maintain indoor comfort and save on energy consumption. However, this strategy contributes to variation in heat load causing the radiators to function mostly at part-load. This is particularly noticeable when switching from night to day time temperature during peak heat demand in the morning [5]. 


\subsection{Heat network}

The DH network provides space heat (SH) for the estate's buildings whereas DHW is provided separately by instantaneous electric heaters. The heat for the DH network is supplied from a $199 \mathrm{~kW}$ biomass condensing boiler during the heating season of September to May. The boiler installation running cost benefits from Renewable Heat Incentive (RHI) scheme, a government scheme to support renewable energy [35]. The biomass boiler uses locally grown and coppiced willow wood chips as fuel. The DH installation also uses a $5 \mathrm{~m}^{3}$ buffer tank and a twin-head hot water circulating pump equipped with variable speed controller. The DH network has a typical tree configuration and is composed of a mix of double and twin pre-insulated pipes. A schematic view of the DH network is presented in Figure 3.

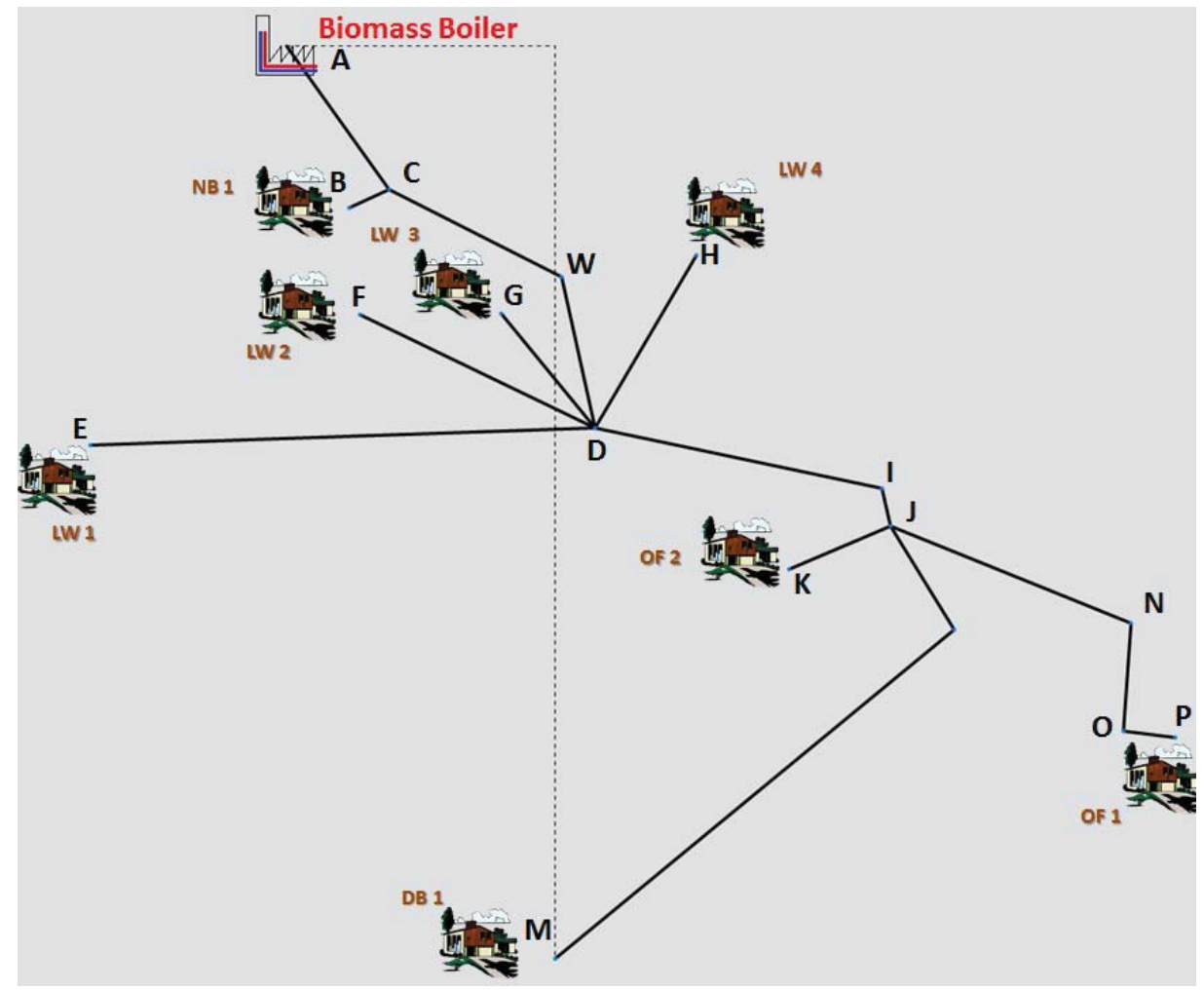

Figure 3: Heat network schematic

The DH network branches are labelled by letters A to P and the network nodes are identified by letter A (heat generating plant) and C, D, J (heat supply to buildings). The design specification of DH network is summarized in 
Table 3: Heat network design

\begin{tabular}{|c|c|c|c|c|c|}
\hline & "Model & Fuel type & $\begin{array}{c}\text { Capacity } \\
(\mathbf{k W})\end{array}$ & discharge mechanism & Thermal storage $\left(\mathrm{m}^{3}\right)$ \\
\hline Boiler & (Lignumat UTSL) & Wood chip & 199 & Spring arm & 5 \\
\hline \multirow[t]{17}{*}{$\begin{array}{l}\text { Pre-Insulated } \\
\text { pipes }\end{array}$} & Branch Pipe & Part name & $\begin{array}{c}\text { Nominal } \\
\text { diameter } \\
(\mathrm{mm})\end{array}$ & $\begin{array}{l}\text { Thermal conductivity } \\
\text { (W/m K) }\end{array}$ & $\begin{array}{l}\text { Length } \\
\text { (m) }\end{array}$ \\
\hline & A-C & Re63Duo** & 51.4 & 0.21 & 42 \\
\hline & $\mathrm{B}-\mathrm{C}$ & Re32Duo** & 26.2 & 0.16 & 6 \\
\hline & C-W & Re63Duo** & 51.4 & 0.21 & 43 \\
\hline & W-D & Re63Duo** & 51.4 & 0.21 & 42 \\
\hline & D-E & Flex40Duo** & 32.6 & 0.23 & 116 \\
\hline & $\mathrm{D}-\mathrm{F}$ & Flex32Duo** & 26.2 & 0.26 & 63 \\
\hline & D-G & Flex32Duo** & 26.2 & 0.26 & 29 \\
\hline & D-H & Flex32Duo** & 26.2 & 0.26 & 36 \\
\hline & D-I & Flex63Uno* & 51.4 & 0.28 & 60 \\
\hline & $\mathrm{I}-\mathrm{J}$ & Flex63Uno* & 51.4 & 0.28 & 5 \\
\hline & $\mathrm{J}-\mathrm{K}$ & Flex32Duo** & 26.2 & 0.26 & 20 \\
\hline & $\mathrm{J}-\mathrm{L}$ & Flex32Duo** & 26.2 & 0.26 & 20 \\
\hline & L-M & Flex32Duo** & 26.2 & 0.26 & 54 \\
\hline & $\mathrm{J}-\mathrm{N}$ & Flex63Uno* & 51.4 & 0.28 & 36 \\
\hline & $\mathrm{N}-\mathrm{O}$ & Flex63Uno* & 51.4 & 0.2 & 20 \\
\hline & $\mathrm{O}-\mathrm{P}$ & Flex63Uno* & 51.4 & 0.2 & 8 \\
\hline
\end{tabular}

The estate combination of old and new buildings meant different types of hydronic heat emitters were installed. For example, the hydronic system of building OF 1, LW 1 and DB 1 are of plate radiator type while the rest of the estate's buildings have underfloor heating (UFH) system. The heater emitters in each building were connected to the DH network through dedicated heat interface units (HIU) which were made of one plate heat exchanger (HE).

Monitoring of the heating system in LW 2 shows that the average supply and return temperature of UFH was $64 / 47^{\circ} \mathrm{C}$ (i.e., $\Delta \mathrm{T}$ of $17^{\circ} \mathrm{C}$ ). This is considered too high compared to good practice in which UFH systems operate at water supply temperatures of $40-50{ }^{\circ} \mathrm{C}$ and $\Delta \mathrm{T}$ of $5-10{ }^{\circ} \mathrm{C}$, with the possibility of even lowering supply temperatures close to $30{ }^{\circ} \mathrm{C}$ in low-energy buildings [14], [28], [36]. This operation anomaly was due to setting the UFH water supply blending-valves to $60{ }^{\circ} \mathrm{C}$ that in the long term could affect the durability of the different components and possibly cause overheating in the occupied spaces, although this was not the case for these buildings as highlighted inFigure 2: Indoor temperature recording for two rooms of building OF 1 and DB 1 . In contrast, the buildings 
served with plate radiators (OF 1, LW1 and DB 1) were set as high supply temperature. Figure 4 represents a sample of recorded hourly temperature variation of the heat network for a period of one week during the heating season of 2014/2015. It was found that the yearly average supply and return temperature of the heat network was $72 / 55^{\circ} \mathrm{C}$.

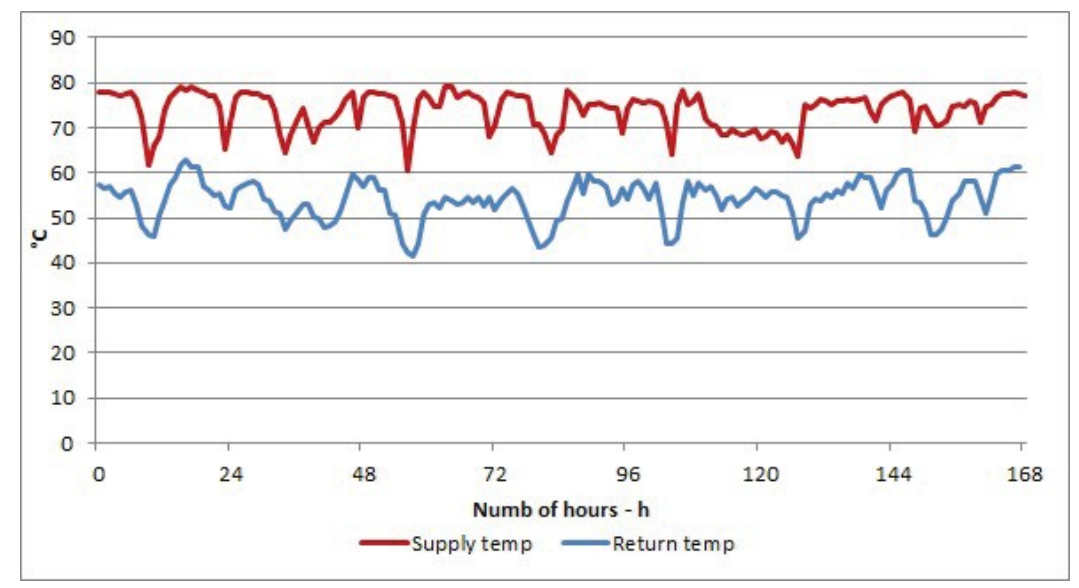

Figure 4: Monitored supply/return temperature of the heat network (20/02/15 to 27/02/15)

Therefore, this work identified an opportunity to set up a new strategy to optimizing the supply and return temperatures at building level to reduce energy an emission of the whole heat network system.

\subsection{Heat network benchmark thermal performance}

The performance of the heat network was initially analysed to reflect the current strategy of controlling thermal comfort in the buildings using night setback strategy. The heating loads associated with each building connected to the heat network were modelled using IDA-ICE software dynamic simulation, taking into account buildings construction properties, occupancy schedule and prevailing local weather condition. Figure 5 illustrates the monthly average heat load of each building. 


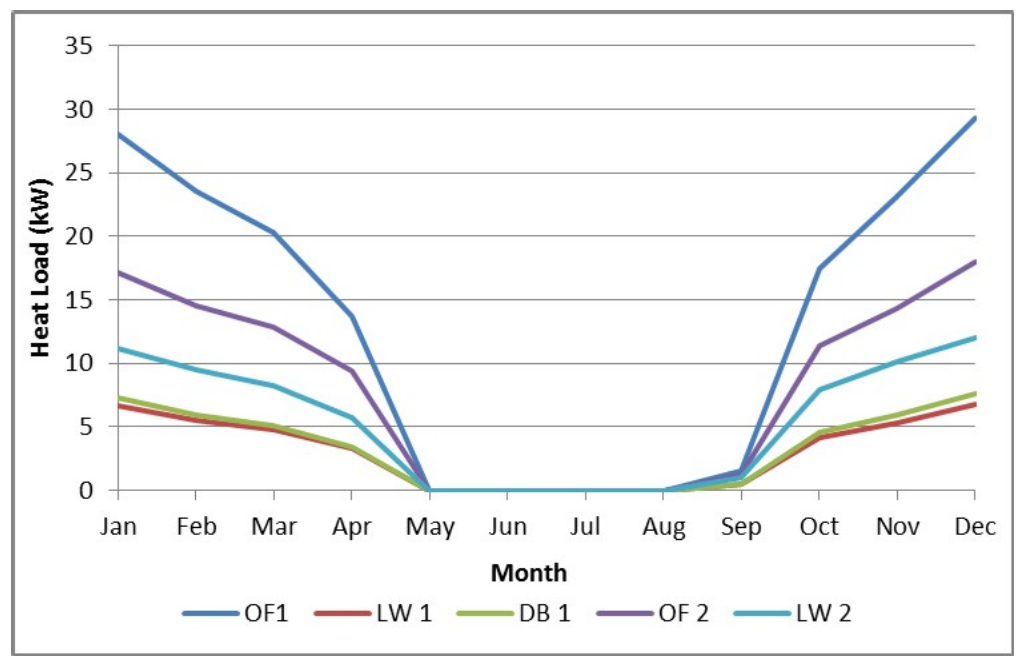

Figure 5: Monthly heat load profile

It can be seen that building OF 1 and OF 2, which have the largest floor area and number of occupants, have the highest heat demands. Being identical, building LW 2, LW 3 and LW 4 individual heat demand is represented by that of LW 2. The estate's buildings annual energy consumption was measured using dedicated heat energy monitoring meters for comparison and validation of simulated results. The results highlight good match between simulation and recorded energy consumption, as shown in Table 4.

Table 4: Comparison between recorded and simulated annual energy consumption

\begin{tabular}{ccc}
\hline \hline Building & \multicolumn{2}{c}{ Energy consumption (MWh/year) } \\
\hline LW 1 & Measured data & Simulation \\
DB 1 & 27.3 & 26.7 \\
LW 2 & 44.7 & 26.6 \\
LW3 & 44.7 & 46.4 \\
LW4 & 44.7 & 46.4 \\
OF 1 & 115.6 & 46.4 \\
OF 2 & 70.4 & 113.5 \\
\hline
\end{tabular}

The DH network and its components (insulated pipes, heat source, pipe nodes, and end-users heat transfer units) were modelled using TERMIS software [37], [38]. The model require the specification of the end-users heat energy consumption profiles, the properties of heat generating plant, water flow temperature, static pressure and monthly average ground temperatures. Table 5 shows results of the simulation and direct measurement of the $\mathrm{DH}$, which include yearly average water return temperature 
of $54.2^{\circ} \mathrm{C}$ compared to measured average return temperature of $55^{\circ} \mathrm{C}$ and a total yearly average energy delivered of $380 \mathrm{MWh}$ which differs by 1.6\% from the average recorded value.

Table 5: Comparison between recorded and simulated results of the heat network operating temperatures

\begin{tabular}{lccc}
\hline \hline \multicolumn{1}{c}{ DH network operating parameters } & Specified data & Recorded data & Simulation data \\
\hline Average supply temperature $\left({ }^{\circ} \mathbf{C}\right)$ & 72 & 72 & - \\
Pressure (bar) & 1.5 & - & 54.2 \\
Average return temperature $\left({ }^{\circ} \mathbf{C}\right)$ & - & 55.0 & 380 \\
Total Energy consumption $(\mathbf{M W h})$ & - & 374.1 & \\
\hline
\end{tabular}

Furthermore, the monthly energy generation, consumption and distribution losses are presented in Figure 6 . The distribution losses represent about $4 \%$ of the annual energy delivered, which is low compared to typical DH energy losses of 10 to 30\% [10], [39], [40], because of small scale of the heat network and duration of operation during heating season only.

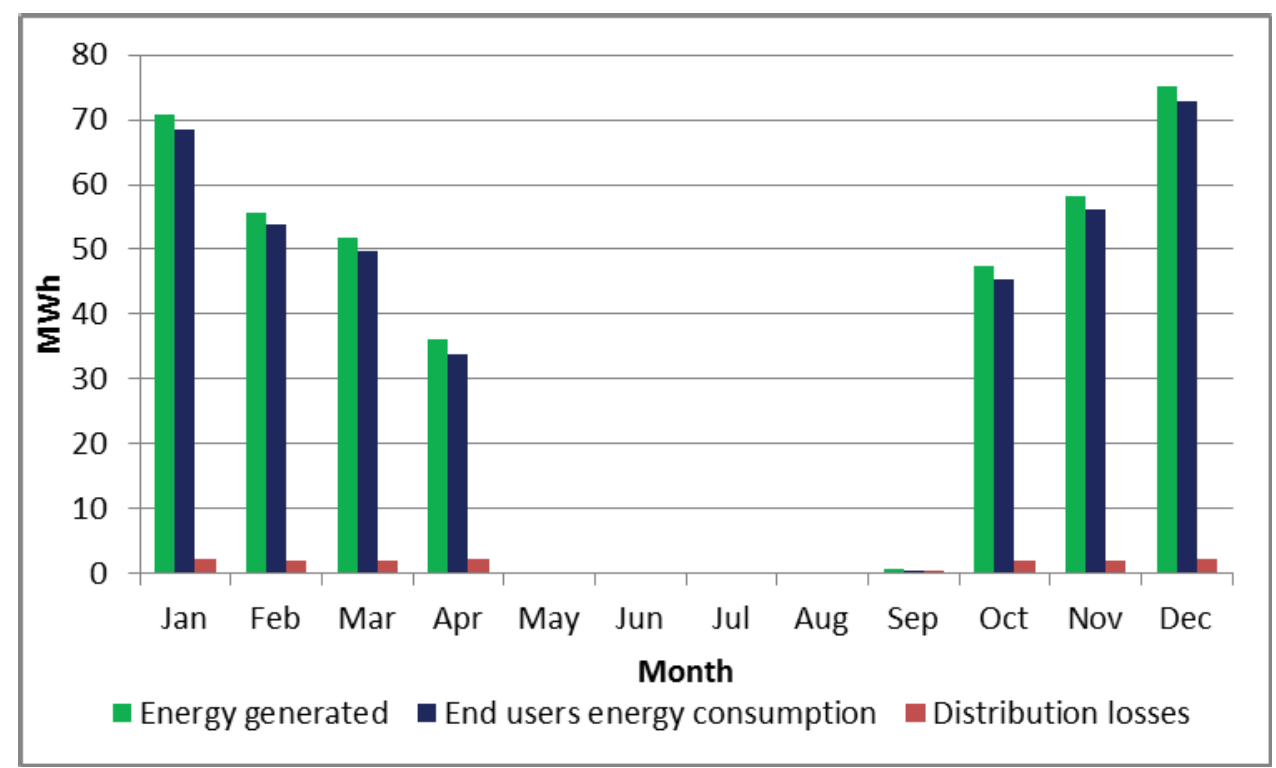

Figure 6: Heat network energy balance: TERMIS results

\section{Methodology}

The heat emitting radiators in buildings served by DH are linked to the heat network either directly or through HIU (flat stations). The radiators are often of flat panels with single or double string configuration designed for a specific $\Delta \mathrm{T}$ and in which hot water supply and return temperature can 
affect the efficiency of the whole DH network. In this work, the temperature optimization procedure of the radiators was formulated to control indoor temperature using a night setback strategy of $21 / 18$ ${ }^{\circ} \mathrm{C}$ for the duration of the heating season. The temperature optimization was conducted in a step by step procedure as shown in Figure 7, a method described in details by the authors in previous work [30].

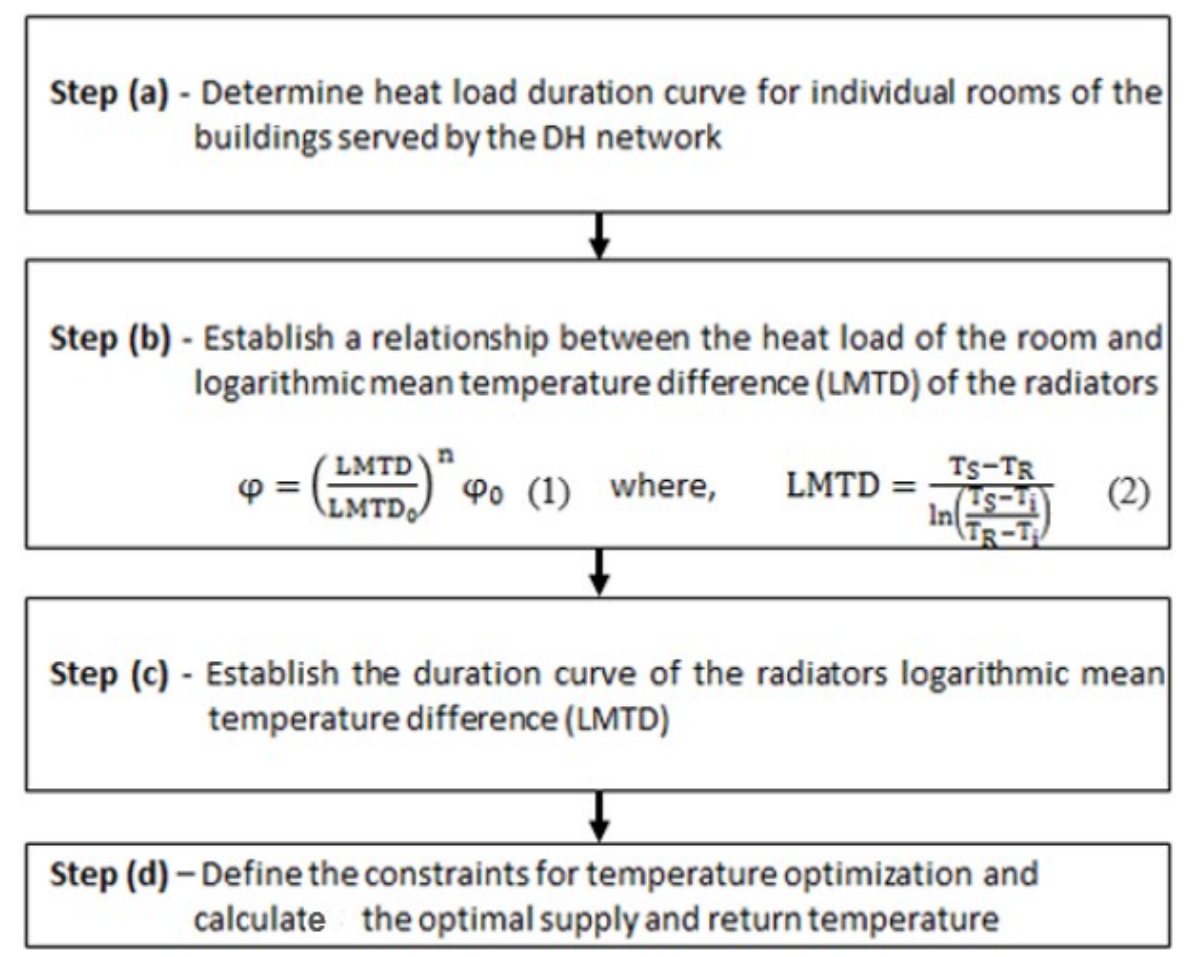

Figure 7: Stepwise procedure for Temperature optimization

In step (a) the heat load of the buildings was simulated using commercial software IDA-ICE [13], [41]-[43], in which the design conditions were defined based on the winter design temperature of -3.9 ${ }^{\circ} \mathrm{C}$ for Nottingham and heat gains neglected, according to CIBSE standards [36]. This led to establishing heat part-load duration curves for each room of the buildings that are equipped with hydronic panel radiators. Subsequently, heat emission capacity of radiators was calculated in step

applying a known empirical relationship (Equation 1), radiator flow/return temperatures and indoor stet point temperature [44], [45].

$$
\frac{\varphi}{\varphi_{0}}=\left(\frac{L M T D}{L M T D_{0}}\right)^{n}
$$


where $\varphi$ and $\varphi_{o}$ are actual and design heat rating of the radiator, LMTD and LMTDo the actual and design logarithmic mean temperature difference and $n$ is an empirical exponent ( $n=1.3$ for panel radiators [15]). The LMTD of the radiator exchanging heat with its surrounding can be given as:

$$
L M T D=\frac{T_{S}-T_{R}}{\ln \left(\frac{T_{S}-T_{i}}{T_{R}-T_{i}}\right)}
$$

where $T_{S}, T_{R}$ and $T_{i}$ are the water supply and return and indoor operative temperatures respectively. Presenting the LMTD of each radiator connected to the DH in the form of duration curves -step (c), an upper limit LMTD curve (representing the worst case) was then constructed and the corresponding water supply and return temperature were taken as the operating temperatures to be satisfied by the heating system during the heating period. Finally, the threshold temperatures of the constructed LMTD duration curve were identified, step (d), and the water supply temperature is set to an appropriate value and held as a constraint while the water return temperature is allowed to vary and considered as an objective function to optimize. The optimization procedure is based on calculating the optimal combination of supply and return temperatures to deliver the needed LMTD for the worst case curve which in turn produces the highest DH system efficiency and economic benefit to enduser.

\section{Results and discussion}

\subsection{Temperature optimization of heating system in buildings with plate radiators}

In this analysis, the focus was on optimising the water supply and return temperature in buildings where heat supplied from DH network is dissipated using plate radiators (i.e., OF 1, LW1 and DB 1). The radiators were equipped with thermostatic radiator valve (TRV) to modulate the water flow rate and in turn the water return temperature and heat output [46], [47]. According to the optimisation algorithm described in methodology section, in step (a) the heat loads were calculated using IDA-ICE and presented as hourly part-load heat duration curves per each room, as shown in Figure 8. 


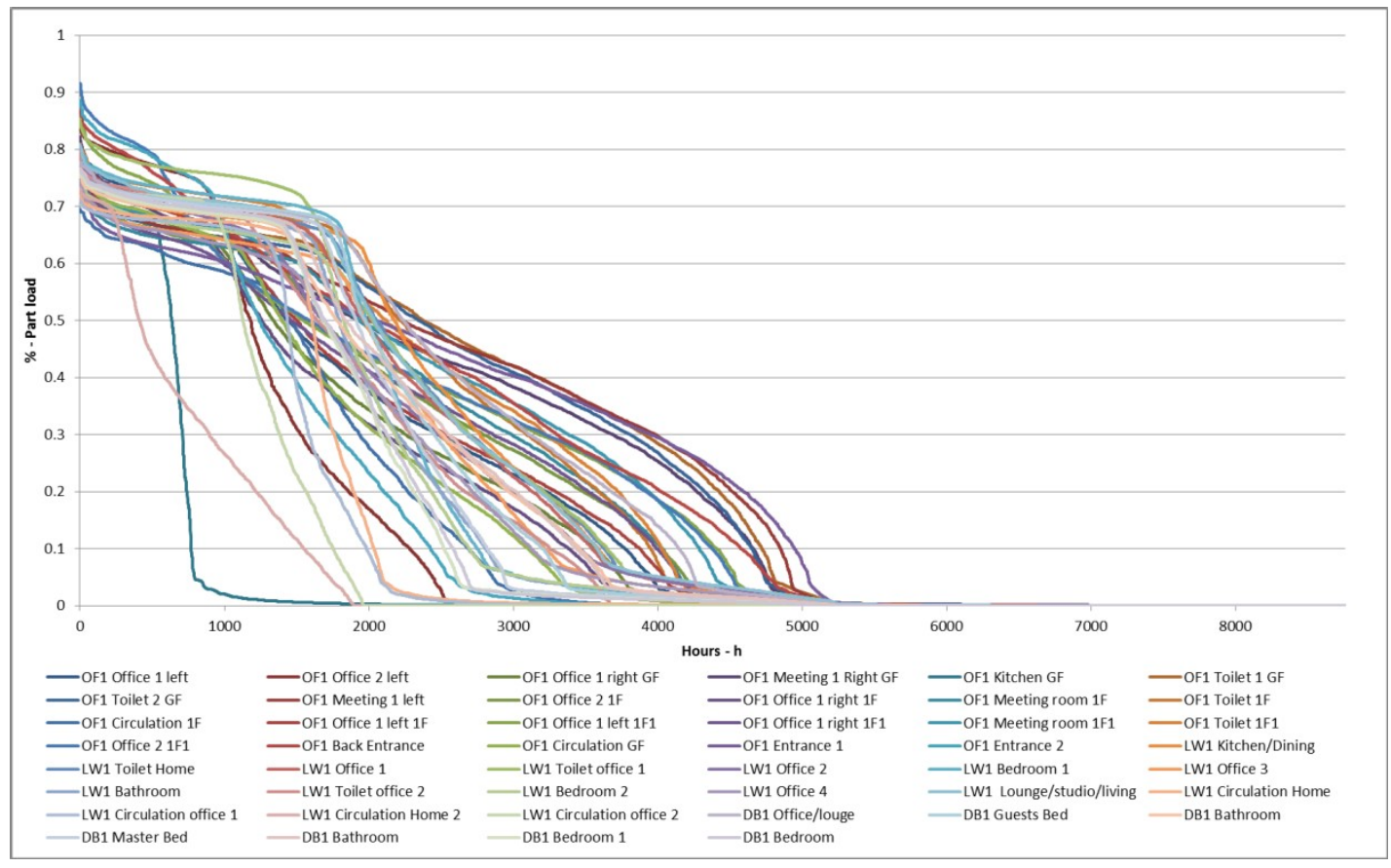

Figure 8: Step a - Plate radiators part load duration curves for each room of buildings OF 1, LW1, and DB 1

The LMTD expresses the heat emitted by a plate radiator and the relation is conveyed in step (b) using Eq. (1) and (2). Taking as an example one room of the building OF 1, as presented in Figure 9, the idea is to illustrate the theoretical operation range of the radiator at different part loads, from no heat demand to design conditions. This however requires the design conditions of the radiators and room temperature be specified. To illustrate the method, OF1 room radiator of design heat output $\Phi_{0}$ of $1940 \mathrm{~W}$, supply and return temperature of $82 / 71{ }^{\circ} \mathrm{C}$, and indoor temperature of $20{ }^{\circ} \mathrm{C}$ were considered in line with current UK practice, resulting in $L M T D_{o}$ of $55.8^{\circ} \mathrm{C}$. This represents the extreme operating regime of the radiator, which occurrence may be limited during normal operation, implying that the radiator will be in in part load mode for majority of the heating season [24], [48], as illustrated in Figure 10. The challenge is therefore to identify the optimal combination of supply and return temperature that will deliver the required LMTD/heat load for all installed radiators. 


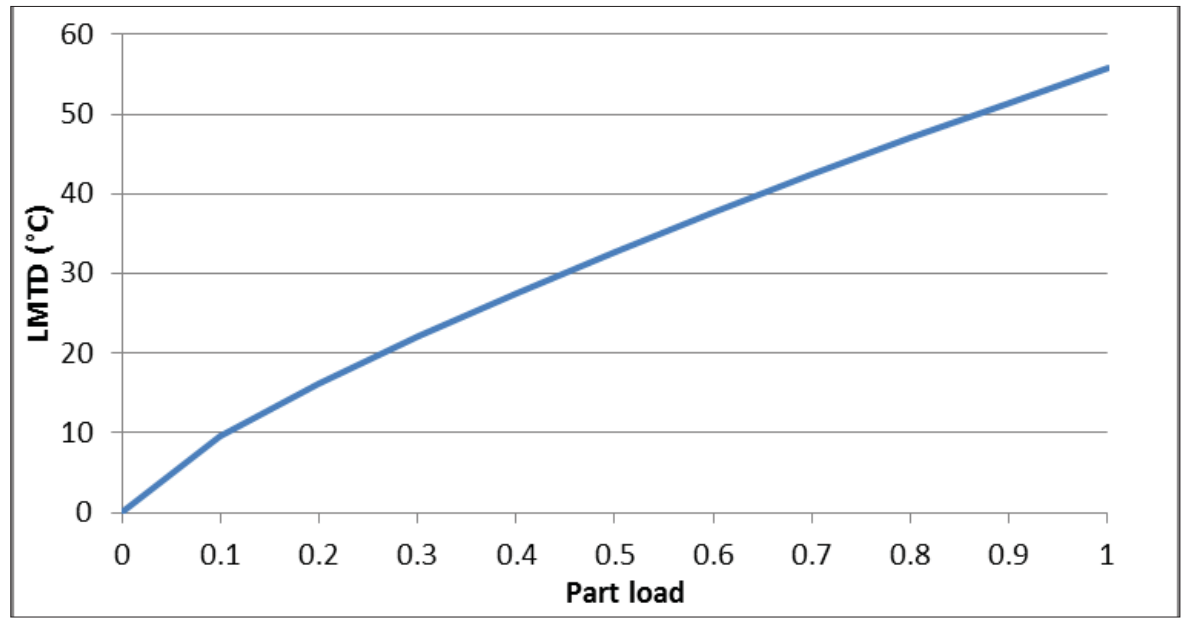

Figure 9: Step (b) - OF1 selected room radiator

The following step is to present each radiators performance by its LMTD duration curve, as illustrated by Figure 10 .

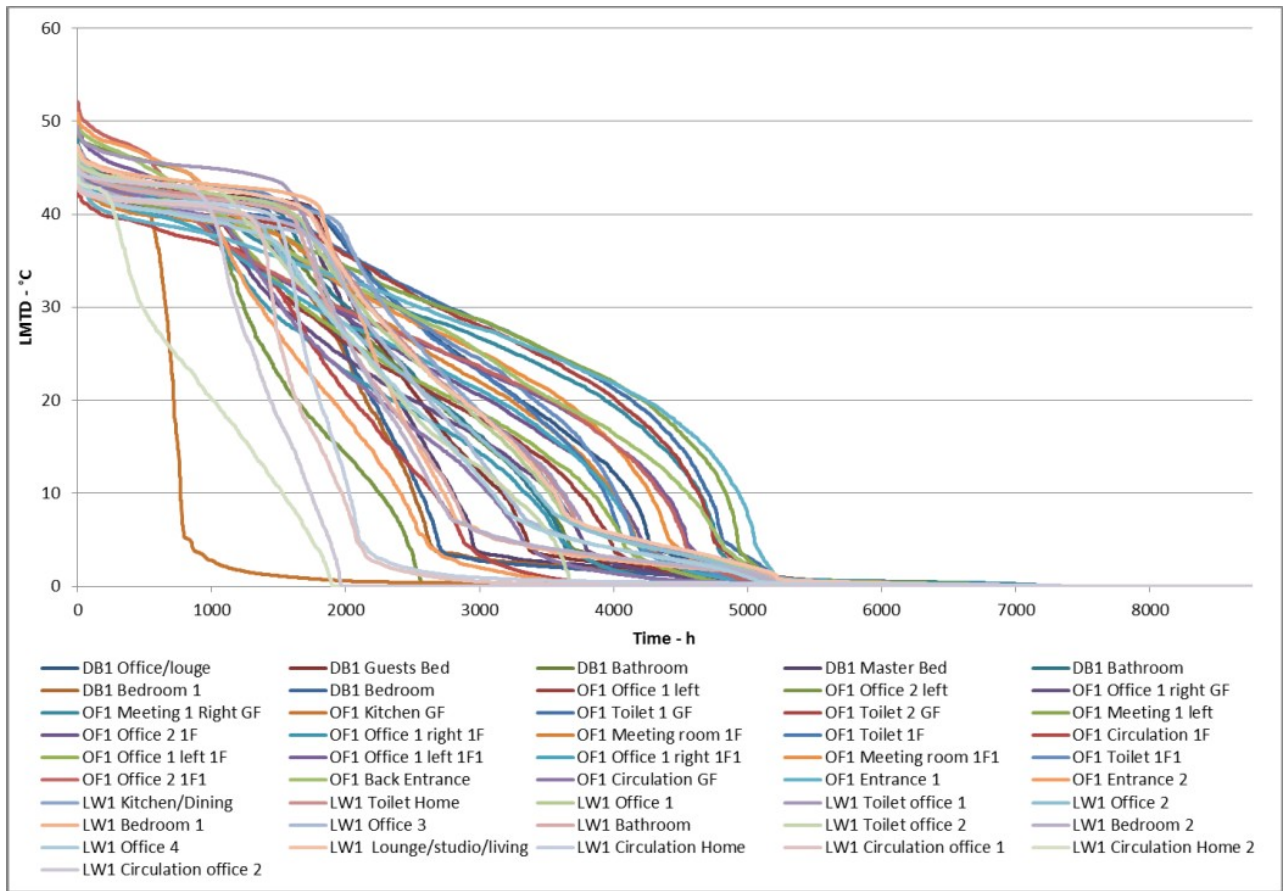

Figure 10: Step (c) - LMTD duration curves of radiators in building OF 1, LW 1 and DB 1

The swarm of LMTD duration curves allows to identify the upper boundary LMTD curve over the duration period as it reflects the high temperature operating conditions for the associated radiators. A construction of the upper boundary LMTD curve delimiting all other curves over the heating season period is shown in Figure 11. It can be seen that that the high temperature design conditions (i.e., LMTD of $55.8^{\circ} \mathrm{C}$ ) did not occur here, which explains that typical design practices tend to oversize heat emitters. 


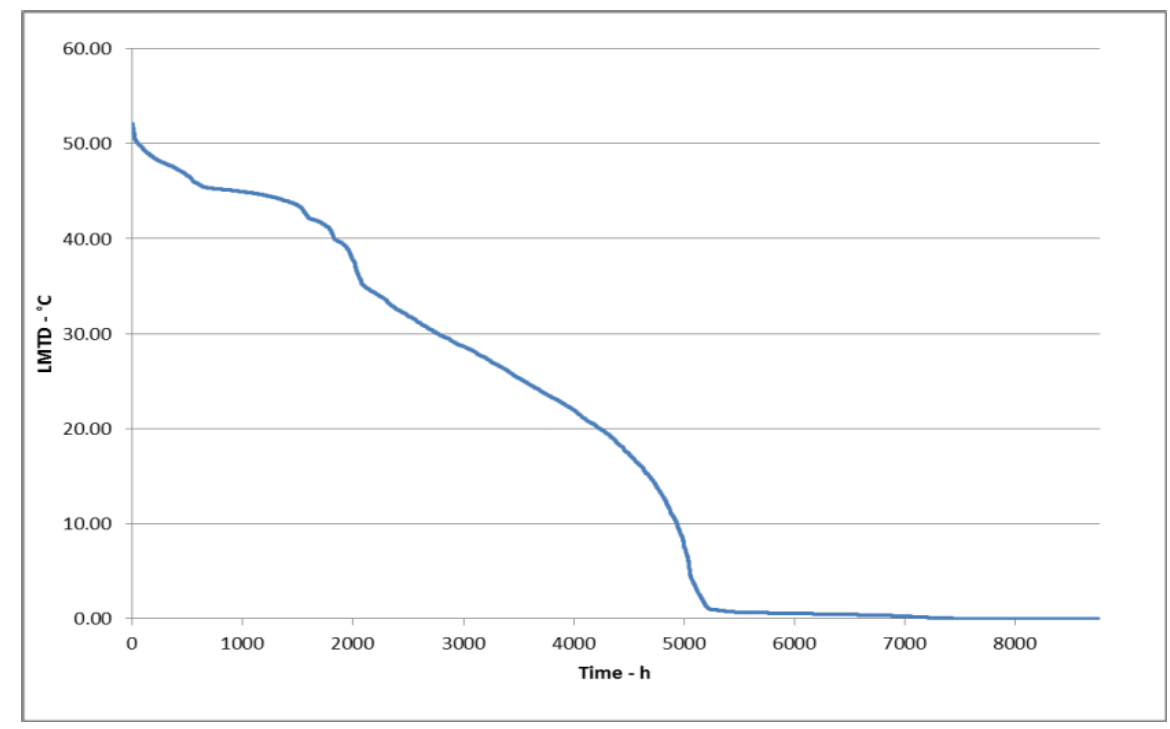

Figure 11: Upper boundary LMTD duration curve

The final step is to define the combinations of supply and return temperatures that satisfy the upper boundary LMTD curve and maintain the indoor thermal comfort strategy at $21^{\circ} \mathrm{C}$ (day) and $18{ }^{\circ} \mathrm{C}$ (night). This was performed by formulating a temperature minimization objective function (i.e., minimizing the radiators supply and return temperatures) and assigning appropriate constraints of temperature and water flow rates, as summarised in Table 6.

Table 6: Objective functions and constraints for indoor temperature of 21 and $18^{\circ} \mathrm{C}$

\section{Indoor temperature}

Day time Night time

$\mathbf{T}_{\mathrm{i}}=21^{\circ} \mathrm{C} \quad \mathbf{T}_{\mathrm{i}}=18^{\circ} \mathrm{C}$

Minimization function

Constraints

$$
\begin{aligned}
& \text { LMTD }<13^{\circ} \mathrm{C} \quad \text { LMTD }<16^{\circ} \mathrm{C} \\
& \min \left(T_{R}\right), \text { for LMTD }=\frac{T_{s}-T_{n}}{\ln \left(\frac{T_{S}-T_{i}}{T_{R}-T_{i}}\right)} \quad T_{S}=50^{\circ} \mathrm{C}, \dot{m} \leq \dot{m}_{0} \\
& 13^{\circ} \mathrm{C} \leq L M T D \leq 22^{\circ} \mathrm{C} \quad 16^{\circ} \mathrm{C} \leq L M T D \leq 27^{\circ} \mathrm{C} \quad \min \left(T_{S}\right), \text { for LMTD }=\frac{T_{s}-T_{R}}{\ln \left(\frac{T_{s}-T_{i}}{T_{R}-T_{i}}\right)} \quad T_{R}=25^{\circ} \mathrm{C}, \dot{m} \leq \dot{m}_{0} \\
& \text { LMTD }>22^{\circ} \mathrm{C} \quad \operatorname{LMTD}>27^{\circ} \mathrm{C} \quad \min \left(T_{R}\right) \text {, for LMTD }=\frac{T_{S}-T_{R}}{\ln \left(\frac{T_{S}-T_{t}}{T_{B}-T_{t}}\right)} \quad T_{S}=82{ }^{\circ} \mathrm{C}, \dot{m} \leq \dot{m}_{0}
\end{aligned}
$$

$T S, T R$ and $T_{i}$ are the supply, return and indoor operative temperatures respectively, $m$ is the mass flow rate $(\mathrm{kg} / \mathrm{h})$ and $m_{O}$ is the mass flow rate at design conditions $(\mathrm{kg} / \mathrm{h})$.

The radiator flow temperatures were constrained between a lower limit of $50{ }^{\circ} \mathrm{C}$, so that the $\mathrm{DH}$ network could supply instantaneous DHW if desired in future upgrades and satisfy current legislation 
on legionella control in building, and an upper limit of $82^{\circ} \mathrm{C}$ as used in current UK high temperature radiator design conditions. Likewise, the water return temperature constraint of $25{ }^{\circ} \mathrm{C}$ was considered to be as close to the indoor room temperatures settings as practically possible. The mass flow rate constraints, on the other hand, depend on the heat capacity of radiator and a design (maximum) value, $m_{o}$ was assigned to selected room radiators as shown in and Table 7.

Table 7: Rooms design heat load and max mass flow rate for the rooms of the upper boundary LMTD duration curve

\begin{tabular}{lcc}
\hline \multicolumn{1}{c}{ Building } & Design heat load (W) & Max mass flow (kg/h) \\
\hline OF 1, Office 2 1F1 & 2374 & 170 \\
OF 1, Entrance 1 & 1295 & 93 \\
OF 1, Entrance 2 & 1462 & 105 \\
OF 1, Meeting room 1 & 8583 & 615 \\
OF 1, Meeting room 2 & 8583 & 615 \\
OF 1, Toilet 1 Ground Floor & 1331 & 95 \\
OF 1, Toilet 1 Ground Floor & 1331 & 95 \\
LW 1, Bedroom 1 & 1399 & 100 \\
LW 1, Kitchen/Dining & 1503 & 108 \\
LW 1, Toilet & 593 & 43 \\
\hline
\end{tabular}

The solution to the optimization problem-temperatures was reached when computed combination of supply and return temperatures fulfilled the stated constraints criteria. The optimal temperatures are presented in Figure 12. It can be noted that there are two break points corresponding at LMTD of 13 ${ }^{\circ} \mathrm{C}$ and $22{ }^{\circ} \mathrm{C}$ for day operation and $16{ }^{\circ} \mathrm{C}$ and $27^{\circ} \mathrm{C}$ for night temperature set back operation. It is also illustrated that for LMTDs smaller than the threshold of 13 and $16{ }^{\circ} \mathrm{C}$ for day and night setting and a supply temperature as low as $50^{\circ} \mathrm{C}$, the optimal return temperatures were lower than the constraint return temperature of $25^{\circ} \mathrm{C}$, as this range of LMTDs require low heat demand and low mass flow rates. Differently, for LMTD higher than 22 and $27^{\circ} \mathrm{C}$, the combination of high heat loads and high mass flow rates led to return temperatures always higher than the target return temperatures and supply temperatures were as high as $\quad 82^{\circ} \mathrm{C}$ to guarantee the expected indoor comfort and avoid unnecessary high return temperatures. 


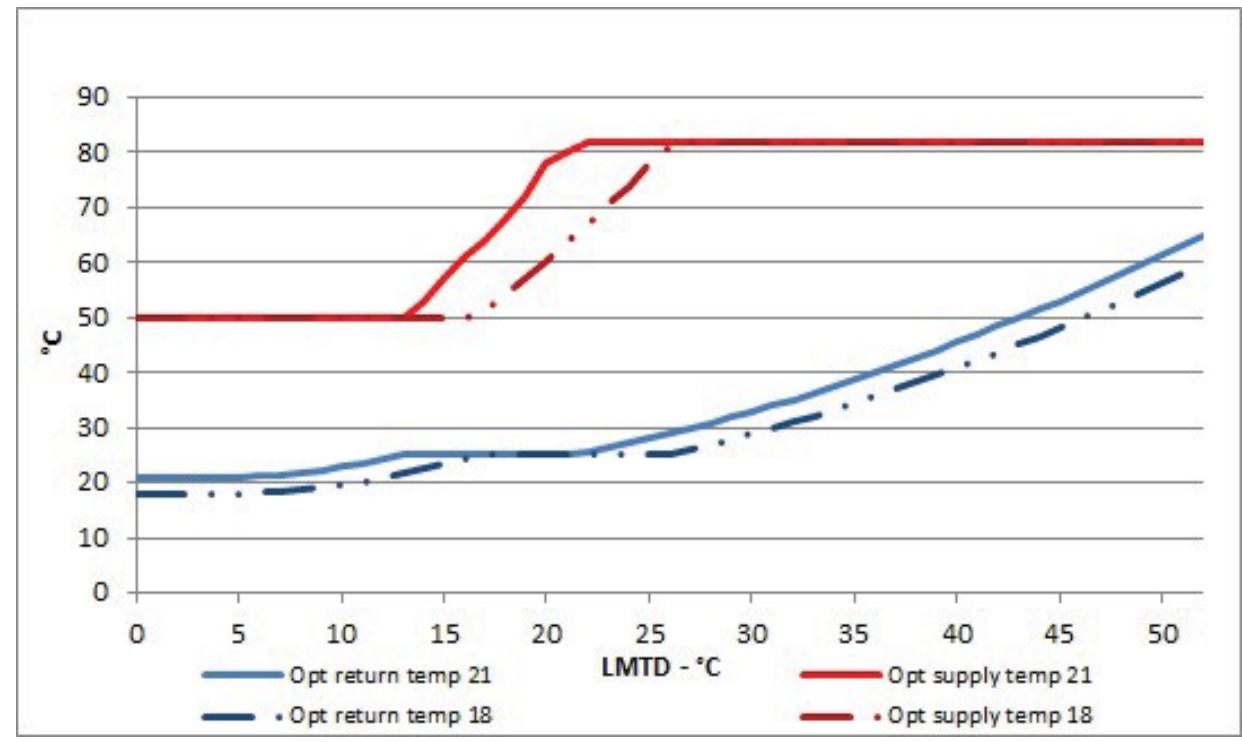

Figure 12: Step (d) - Optimal combination of radiator supply and return temperatures

This work shows particularly that it is possible to operate existing radiators arrangement at lower return temperatures and still provide sufficient heat to maintaining indoor design temperature with simple adjustment to heating controls. The optimisation conditions of the existing plate radiators over the range of LMTDs would lead to a new average supply and return temperatures of $81 / 41{ }^{\circ} \mathrm{C}$ for the buildings equipped with plate radiators over the considered heating season. However, the size of the existing radiators has an impact on the capacity of guaranteeing the same indoor comfort when lowering operating temperatures. Hence, the optimal temperatures obtained were influenced by the UK design practise of using high temperatures and small $\Delta \mathrm{T}$ that typically results in installing smaller radiators. Therefore, improving energy efficiency in buildings served by DH could also benefit from upgrading plate radiators installations.

Furthermore, lowering the return temperature in DH networks improves the overall efficiency by ensuring the biomass boiler is operating in condensing mode and hence reduce fuel consumption, benefitting economically the DH network operator. However, for the strategy to succeed, the DH operators need to engage with end-users through offering technical support, upgrading of heat emitters and discounted energy bills in proportion to lowering return temperature below a set threshold. This is currently common practice in countries such as Denmark where the end users are incentivized through 'motivation tariff' to maintain the user's average return temperature lower that 
the whole DH network average return temperature. The current motivation tariff provides $1 \%$ discount of the end-user's energy bill for each $1{ }^{\circ} \mathrm{C}$ drop in return temperature below the network average return temperature up to a maximum of 20\% discount [49]. Applying the motivation energy incentive in this study would discount the end user's energy bill by $14 \%$ simply by reducing the return temperature from the current average of $55^{\circ} \mathrm{C}$ to the optimum average of $41^{\circ} \mathrm{C}$, savings that can be afforded through higher overall system energy efficiency as discussed in the following section.

\subsection{Heat network results: performance improvement}

The operation of the DH network was reassessed based on the optimised water supply and return temperature of $81 / 41^{\circ} \mathrm{C}$ using TERMIS software. It was also found in this case that the buildings with UFH were operated unnecessary at high temperatures as the HIU blending valve was set at $60{ }^{\circ} \mathrm{C}$, causing higher return temperatures. Therefore, in the TERMIS model, it was assumed that supply and return temperature for UFH system could be set at $40 / 30{ }^{\circ} \mathrm{C}$ to reflect current practice for UFH systems operation. The analysis yielded a $\mathrm{DH}$ annual average hot water return temperature of $35.6{ }^{\circ} \mathrm{C}$, a drop of $19.4{ }^{\circ} \mathrm{C}$ compared to present operating temperature of $55{ }^{\circ} \mathrm{C}$ and a circulating pump flow rate of $1450 \mathrm{~kg} / \mathrm{h}$ compared to the reference case, as summarized in Table 8.

Table 8: TERMIS simulation: heat network comparison between reference and optimized scenario

\begin{tabular}{lcc}
\hline \multicolumn{1}{c}{ Heat Network results } & Reference case & Optimized Scenario \\
\hline Average return temperature $\left({ }^{\circ} \mathrm{C}\right)$ & 54.2 & 35.60 \\
Energy generated (MWh) & 395.03 & 393.75 \\
Energy delivered (MWh) & 380 & 380 \\
Distribution losses (MWh) & 15.03 & 13.75 \\
Mass flow rate (kg/h) & 3790 & 1450 \\
Pressure (bar) & 1.5 & 1.5 \\
\hline
\end{tabular}

The monthly energy balances of the optimised DH network simulation results are presented in Figure 13. Compared to the benchmark results of energy consumption, the proposed strategy shows the distribution losses make $3.6 \%$ of the total energy delivered, corresponding to an improvement of $10 \%$ for the entire heat network. 


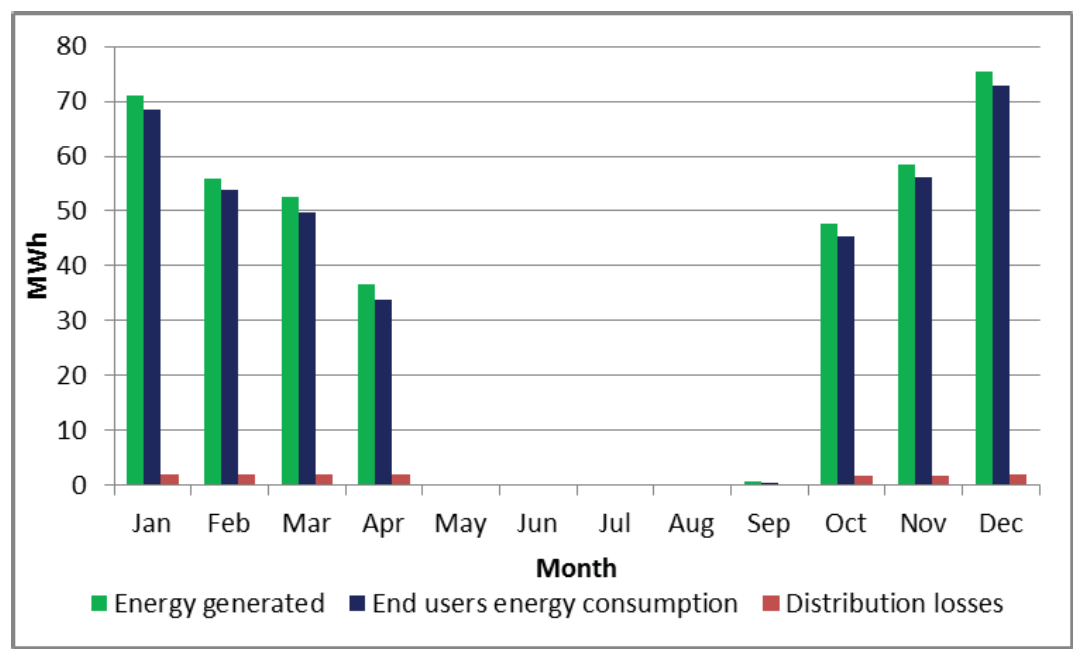

Figure 13: TERMIS simulations - Energy balance of the optimized heat network

The obtained results can be achieved in the network without any invasive renovation of the system, yet simply adjusting and controlling temperatures and flow rates circulating in the network and in the heating systems. Though, the success of the strategy proposed is strictly linked to the control of the radiator systems and UFH. As reported by Liao et al. [50], in the UK, although TRVs are installed in almost every systems, it was found that in majority of cases they were poorly perform mainly due to wrong human behaviours. Hence, the DH operator has to directly engage with the end-users and make sure the heating systems are correctly controlled to minimize the risk of over-flow in the TRVs [51] and the consequent higher return temperatures. Furthermore, lower average water return temperature $\left(35.6^{\circ} \mathrm{C}\right.$ ) allowed the boiler to operate in condensing mode, achieving marginal improvement in combustion efficiency from $86 \%$ to $94 \%$, as illustrated in Figure 14 [52].

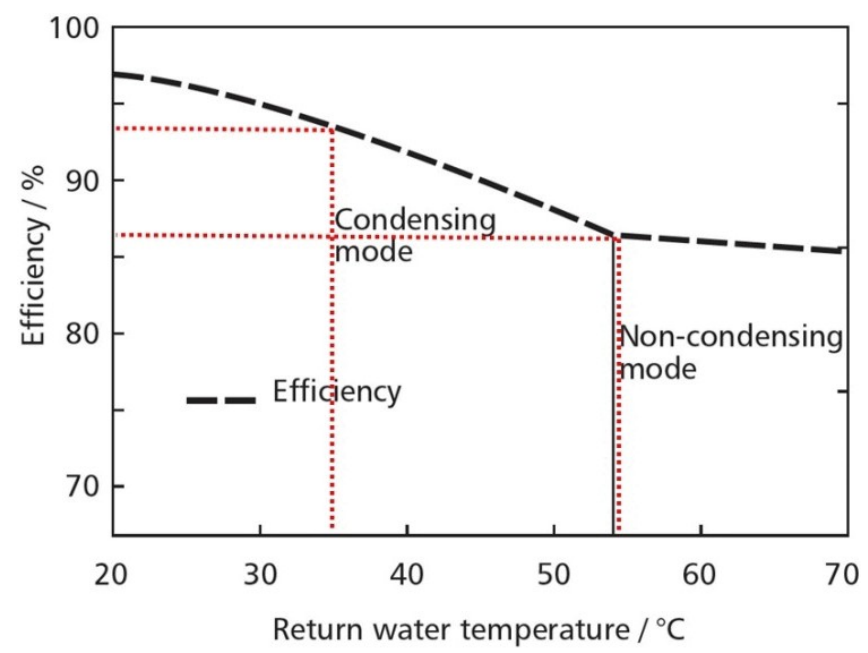

Figure 14: Marginal efficiency improvement of biomass boiler 
The biomass fuel (wood chips) properties used in the DH boiler had an estimated net calorific value (NCV) of $3.5 \mathrm{kWh} / \mathrm{kg}$ for moisture content of 30\% [53] and the annual mass of fuel burnt can be expressed as follows:

$$
m_{f}=\left(\frac{E_{g}}{N C V \cdot n_{b} \cdot 1000}\right)
$$

where $m_{f}$ is the mass of fuel (tonne), $E_{g}$ is the annual energy generated (kWh), NCV is the net calorific value of fuel and $\eta_{b}$ is the relative efficiency of the boiler. Comparing the mass of fuel used in reference and optimized case, it was estimated that a reduction of $9 \%$ in the fuel consumption was achieved.

The curves proposed can also be used by a DH operator to plan a renovation strategy for improving the performances of the system. For instance, working closely with the end-users, the rooms/radiators aggregated in the worst LMTD curve of Figure 11 can be inspected and a replacement of the critical heat emitters, as also reported by Østergaard and Svendsen [54], as well as a renovation of the building envelop could be planned. Once these enhancements would be addressed, the curve of Figure 11 would be improved according to the level of renovation and as a consequence, new lower optimal operating temperatures could be achieved in the systems.

\section{Conclusion}

This paper demonstrated that optimizing hot water supply and return temperatures in a district heating system can improve the overall thermal performance of the network. The optimization methodology was demonstrated through the study of a small scale DH network in UK that serves a small estate buildings with a mix of activities, occupancy and type of heat emitters (radiators and underfloor heating).

Retaining the existing night temperature setback strategy of $21 / 18{ }^{\circ} \mathrm{C}$ for thermal comfort, the optimization of the operation conditions for the radiators in building OF 1, LW 1 and DB 1, efficiently controlled through TRVs, led to a reduction in average hot water return temperature to $41{ }^{\circ} \mathrm{C}$ and an equivalent discount in end-user energy bill of $14 \%$. Further investigation showed that the UFH was operated at too high temperature of $60{ }^{\circ} \mathrm{C}$. Implementing the proposed optimal radiators operating temperatures and reducing the operating temperature of the UFH to 
$40 / 30{ }^{\circ} \mathrm{C}$, the simulation of the heat network system using TERMIS software shows a reduction of $19.4^{\circ} \mathrm{C}$ in the average return temperature. This resulted in reducing the heat network heat losses and boiler fuel consumption by $10 \%$ and $9 \%$ respectively. Therefore, the study demonstrates the viability of the optimization method in improving district heat networks through simple hot water temperature adjustment that is responsive to end users heat demand, while affording the same level of comfort.

Finally, this study showed that energy efficiency of DH in the UK can be improved by fine tuning supply and return temperatures and flow rates without causing invasive renovation of the end user heating systems. Although it is mandatory under UK building regulation that heating controls are installed in buildings, often it was found the controls perform poorly because they were set incorrect setting by the end user. Therefore, DH operator's direct engagement with endusers to provide technical support and customized energy bills based on the operation of the heat installation is vital to the success of the strategy. For instance, the LMTD duration curves of the radiators can be used by the DH operator to plan an appropriate renovation strategy to the building envelope, the heating installations or both as a course to lowering operating temperatures and improving overall heat network thermal performance.

\section{Acknowledgments}

The authors wish to thank SASIE Ltd, Hexgreave Estate and the Civil Engineering Department of DTU, for sponsoring and providing all the support necessary to complete this research project.

\section{Reference}

[1] DECC, "The Future of Heating : Meeting the challenge," 2013.

[2] DECC, "Heat Pumps in District Heating: Final report," 2016.

[3] Commitee on Climate Change, "The Fourth Carbon Budget: Reducing Emissions Through the 1990s," 2010.

[4] DECC, "The Future of Heating: A strategic framework for low carbon heat in the UK," DECC, 2012.

[5] S. Frederiksen and S. Werner, District Heating and Cooling. Sweden: Studentlitteratur, pag. 408, 2013.

[6] H. Lund et al., "4th Generation District Heating (4GDH). Integrating smart thermal grids into 
future sustainable energy systems.,” Energy, vol. 68, pp. 1-11, 2014.

[7] A. Dalla Rosa et al., "Toward 4 th Generation District Heating : Experience and Potential of Low-Temperature District Heating,” 2014.

[8] P. K. Olsen, C. H. Christiansen, M. Hofmeister, S. Svendsen, and J.-E. Thorsen, "Guidelines for Low-Temperature District Heating,” 2014.

[9] M. Brand and S. Svendsen, "Renewable-based low-temperature district heating for existing buildings in various stages of refurbishment,” Energy, vol. 62, pp. 311-319, 2013.

[10] M. Kofinger, D. Basciotti, R. R. Schmidt, E. Meissner, C. Doczekal, and A. Giovannini, "Low temperature district heating in Austria: Energetic, ecologic and economic comparison of four case studies," Energy, vol. 110, pp. 95-104, 2016.

[11] M. Brand, P. Lauenburg, J. Wollerstrand, and V. Zboril, "Optimal Space Heating System for Low-Energy Single-Family House Supplied by Low-Temperature District Heating,” in Passivhusnorden, 2012.

[12] A. Dalla Rosa and J. E. Christensen, "Low-energy district heating in energy efficienty building areas," Energy, vol. 36, 2011.

[13] P. Ovchinnikov, A. Borodinecs, and K. Strelets, "Utilization potential of low temperature hydronic space heating systems: A comparative review,” Build. Environ., vol. 112, pp. 88-98, 2016.

[14] P. Weitzmann, "Modelling building integated heating and cooling systems," 2004.

[15] B. Young, A. Shiret, J. Hayton, and W. Griffiths, "Design of low-temperature domestic heating systems,” BRE, 2013.

[16] D. S. Østergaard and S. Svendsen, "Theoretical overview of heating power and necessary heating supply temperatures in typical Danish single-family houses from the 1900s," Energy Build., vol. 126, pp. 375-383, 2016.

[17] B. S. Institution, BS 8558: Guide to the design, installation, testing and maintenance of services supplying water for domestic use within buildings and their curtilages Complementary guidance to BS EN 806, Second. BSI, 2015.

[18] HSE, Legionnaires ' disease. The control of legionella bacteria in water systems, Fourth edi. Health and Safety Executive, 2013.

[19] HSE, Legionnaires ' disease. Part 2: The control of legionella bacteria in hot and cold water systems. Health and Safety Executive, 2014.

[20] "Danish Standard, DS 469 - Heating and cooling systems in buildings.” 2013.

[21] X. Yang, H. Li, and S. Svendsen, "Decentralized substations for low-temperature district heating with no Legionella risk, and low return temperatures,” Energy, vol. 110, pp. 65-74, 2016.

[22] X. Yang, H. Li, and S. Svendsen, "Evaluations of different domestic hot water preparing methods with ultra-low-temperature district heating,” Energy, vol. 109, pp. 248-259, 2016.

[23] X. Yang, H. Li, and S. Svendsen, "Energy, economy and exergy evaluations of the solutions for supplying domestic hot water from low-temperature district heating in Denmark," Energy Convers. Manag., vol. 122, pp. 142-152, 2016.

[24] P. Lauenburg, "Temperature optimization in district heating systems," in Advanced District Heating and Cooling (DHC) Systems, Elsevier Ltd., 2016, pp. 223-240.

[25] S. Paiho and F. Reda, "Towards next generation district heating in Finland,” Renew. Sustain. Energy Rev., vol. 65, pp. 915-924, 2016.

[26] Q. Wang, Low-temperature Heating in Existing Swedish Residential Buildings - Toward Sustainable Retrofitting, no. October. 2016.

[27] B. Skagestad and P. Mildenstein, District Heating and Cooling Connection Handbook. 2002.

[28] R. Wiltshire, J. Williams, and A. Rajan, "The importance of energy quality in matching supply and demand,” BRE press, 2012.

[29] CIBSE and ADE, Heat networks : Code of Practice for the UK Raising standards for heat supply. CIBSE, 2015.

[30] M. Tunzi, D. S. Østergaard, S. Svendsen, R. Boukhanouf, and E. Cooper, "Method to investigate and plan the application of low temperature district heating to existing hydraulic radiator systems in existing buildings,” Energy, vol. 113, pp. 413-421, 2016.

[31] Office of the Deputy Prime Minister, "The Building Regualtions 2006: L1A-Conservation of 
fuel and power in new dwellings,” Off. Deputy Prime Minist., no. April, 2006.

[32] Office of the Deputy Prime Minister, "The Building Regualtions 2006: L2A-Conservation of fuel and power in new dwellings,” no. April, pp. 1-39, 2006.

[33] English Heritage, “Energy Efficiency and Historic Buildings,” no. April, pp. 1-61, 2012.

[34] CIBSE, CIBSE Guide A - Environmental Design. 2006.

[35] Ofgem, “Ofgem non-domestic RHI for Great Britain.” [Online]. Available: https://www.ofgem.gov.uk/environmental-programmes/non-domestic-renewable-heatincentive-rhi/tariffs-apply-non-domestic-rhi-great-britain.

[36] CIBSE, “CIBSE Guide B: Heating , ventilating , air conditioning and refrigeration,” 2006.

[37] A. Dalla Rosa, R. Boulter, K. Church, and S. Svendsen, "District heating (DH) network design and operation toward a system-wide methodology for optimizing renewable energy solutions (SMORES) in Canada: A case study,” Energy, vol. 45, no. 1, pp. 960-974, 2012.

[38] Schneider Electric, “TERMIS software.” [Online]. Available: http://www.schneiderelectric.com/en/product-range/61418-termis-software/.

[39] B. Elmegaard, T. S. Ommen, M. Markussen, and J. Iversen, "Integration of space heating and hot water supply in low temperature district heating,” Energy Build., 2015.

[40] J. Danielewicz, B. Śniechowska, M. A. Sayegh, N. Fidorów, and H. Jouhara, "Threedimensional numerical model of heat losses from district heating network pre-insulated pipes buried in the ground," Energy, vol. 108, pp. 172-184, 2016.

[41] M. Maivel and J. Kurnitski, "Low temperature radiator heating distribution and emission efficiency in residential buildings,” Energy Build., vol. 69, pp. 224-236, 2014.

[42] M. Maivel and J. Kurnitski, "Radiator and floor heating operative temperature and temperature variation corrections for EN 15316-2 heat emission standard,” Energy Build., vol. 99, pp. 204-

[43] D. S. Østergaard and S. Svendsen, "Replacing critical radiators to increase the potential to use low-temperature district heating - A case study of 4 Danish single-family houses from the 1930s," Energy, 2016.

[44] "European Standard - EN 442 -1 - Radiators and Convectors Part 1: Technical specifications and requirements.” 2015.

[45] "European Standard - EN 442-2 - Radiators and Convectors Part 2: Test methods and rating.” 2015.

[46] R. Petitjean, Balancing radiator systems, vol. 3, no. 3. TA \& Andersson AB, 2003.

[47] B. Xu, A. Huang, L. Fu, and H. Di, "Simulation and analysis on control effectiveness of TRVs in district heating systems,” Energy Build., vol. 43, no. 5, pp. 1169-1174, 2011.

[48] D. Østergaard and S. Svendsen, "Space heating with ultra-low-temperature district heating - a case study of four single-family houses from the 1980s," Energy Procedia, vol. 116, pp. 226235, 2017.

[49] "Middelfart Fjernvarme [info and data in Danish]," 2015. [Online]. Available: http://www.middelfartfjernvarme.dk/wp-content/uploads/2015/09/Middelfart-FjernvarmeIndførelse-af-motivationstarif-PIXI-udgave.pdf. [Accessed: 01-Oct-2015].

[50] Z. Liao, M. Swainson, and a. L. Dexter, "On the control of heating systems in the UK," Build. Environ., vol. 40, no. 3, pp. 343-351, 2005.

[51] D. Schmidt et al., "Low Temperature District Heating for Future Energy Systems," Energy Procedia, vol. 116, pp. 26-38, 2017.

[52] CIBSE, "Energy efficiency in buildings - CIBSE Guide F,” CIBSE, 2016.

[53] Biomass energy centre, "Typical calorific values of fuels." [Online]. Available: http://www.biomassenergycentre.org.uk/portal/page?_pageid=75,20041\&_dad=portal.

[54] D. S. Østergaard and S. Svendsen, "Replacing critical radiators to increase the potential to use low-temperature district heating - A case study of 4 Danish single-family houses from the 1930s,” Energy, vol. 110, pp. 75-84, 2016. 


\section{List of symbols and acronyms}

\begin{tabular}{|c|c|}
\hline DH & District heating \\
\hline LTDH & Low-temperature district heating \\
\hline LMTD & Logarithmic mean temperature difference $\left({ }^{\circ} \mathrm{C}\right)$ \\
\hline $\mathbf{L M T D}_{0}$ & Logarithmic mean temperature difference at design condition $\left({ }^{\circ} \mathrm{C}\right)$ \\
\hline$\Delta T$ & Temperature difference between supply and return temperature $\left({ }^{\circ} \mathrm{C}\right)$ \\
\hline TRV & Thermostatic radiator valve \\
\hline SH & Space heating \\
\hline DHW & Domestic hot water \\
\hline$\varphi$ & Heating power at operating temperatures (W) $\boldsymbol{\varphi}_{0}$ \\
\hline & Nominal heating power at design conditions (W) \\
\hline n & Radiator exponent \\
\hline$m$ & Mass flow rate $(\mathrm{kg} / \mathrm{h})$ \\
\hline$m_{O}$ & Max mass flow rate at design conditions(kg/h) \\
\hline $\mathbf{C}_{\mathbf{p}}$ & Specific heat capacity of water $\left(\mathrm{J} / \mathrm{kg}{ }^{\circ} \mathrm{C}\right)$ \\
\hline$T_{s}$ & Supply temperature $\left({ }^{\circ} \mathrm{C}\right)$ \\
\hline$T_{R}$ & Return temperature $\left({ }^{\circ} \mathrm{C}\right)$ \\
\hline$T_{i}$ & Indoor temperature $\left({ }^{\circ} \mathrm{C}\right)$ \\
\hline
\end{tabular}

